\title{
Financial Outcomes in Adolescence and Early Adulthood in Australian Longitudinal Data
}

\author{
John de New, David Ribar, Christopher Ryan, Clement Wong ${ }^{1}$ \\ November 2019
}

\begin{abstract}
This article describes and catalogues person-specific measures of financial outcomes that are available for adolescents and young adults in three large longitudinal Australian surveys: the Longitudinal Surveys of Australian Youth, the Longitudinal Study of Australian Children, and the Household, Income and Labour Dynamics in Australia Survey. It summarises international research that has been conducted on young people's financial outcomes, illustrating outcomes that have been investigated, research questions that have been asked, and distinctions that have been drawn between adolescents and young adults. It considers the strengths and weaknesses of the three surveys for extending this research into the Australian context.

JEL: D14, G51
\end{abstract}

\section{Introduction}

Young people’s financial situations are increasingly perilous, with the current generation of young adults in many countries confronting more debt, higher nondiscretionary expenses, lower rates of home ownership, and lower net wealth than

\footnotetext{
${ }^{1}$ Corresponding author: Clement Wong, Clement.Wong@unimelb.edu.au. All authors affiliated with the Melbourne Institute: Applied Economic and Social Research, University of Melbourne, 111 Barry Street, FBE Building, Level 5, Carlton VIC 3053, Australia. The authors gratefully acknowledge financial support from Commonwealth Bank of Australia. The article draws on material from the authors’ report Haisken-DeNew et al., (2019), A Conceptual Framework to Measure Young Australians' Financial Wellbeing, referenced in this study. The findings and views reported in this article are those of the authors only and do not necessarily represent Commonwealth Bank of Australia or the Melbourne Institute.
}

This is the author manuscript accepted for publication and undergone full peer review but has not been through the copyediting, typesetting, pagination and proofreading process, which may lead to differences between this version and the Version of Record. Please cite this article as doi: 10.1111/1467-8462.12361.

This article is protected by copyright. All rights reserved. 
earlier generations (Houle 2014; Lobaugh et al., 2019; Wood et al., 2019). Changes in financial circumstances are likely contributing to delays in steps in the transition to adulthood, including nest-leaving, achieving financial independence from parents, partnering, and family formation.

Many studies consider the economic resources that are available to adolescents and young adults from earnings and employment, family transfers, and public assistance. A smaller but growing set of studies examines the financial outcomes that stem from those resources, including young people’s spending, saving, borrowing, financial planning, financial management, and financial hardships. Investigating these outcomes is important for understanding the behaviours and wellbeing of young people and understanding how young people become economic actors though developmental processes, financial socialisation, family bargaining, and other routes (Drever et al. 2015; Gudmunson and Danes, 2011; Jorgensen et al., 2017; Lundberg et al., 2009). This research is also needed to evaluate changes in young people's circumstances, such as the steep run-up in Australian housing costs, youth-focused programs, such as the Youth Allowance program and Higher Education Contribution Scheme (HECS), and interventions, such as financial literacy education.

The limited attention paid to young people's financial outcomes may reflect their dependent status and an assumption that their financial wellbeing is the same as their household's financial wellbeing. It may also reflect constraints on the availability of data on young people’s financial outcomes and financial contexts.

Data constraints are less of an issue in Australia. Australia boasts three large national longitudinal surveys that gather person-level information about young people’s finances: the Longitudinal Surveys of Australian Youth (LSAY), the 
Longitudinal Study of Australian Children (LSAC), and the Household, Income and Labour Dynamics in Australia (HILDA) Survey. These surveys can support many studies on young people’s financial outcomes, circumstances, and follow-on outcomes. The objective of this article is to review and evaluate the content of these three surveys for use in these types of studies.

The article begins by briefly reviewing studies of young people’s financial outcomes-mostly with an eye towards illustrating the types of outcomes that have been investigated and pointing to the types of research questions that have been asked. It then turns to a detailed description of each of the three surveys, including the survey structure and universe, the financial variables that are recorded for young people at different ages, and other measures that are relevant for studying financial outcomes. The article concludes with a critical evaluation of the strengths and weaknesses of the surveys for research on young people’s finances.

\section{Literature Review}

Financial research on adolescents and young adults tends to consider different outcomes for each group, reflecting the changes in economic activities, responsibilities, and relationships young people experience as they age. Considerations for studies on adolescents include their modest levels of resources, limited financial responsibilities and autonomy, and dependence on parents. In contrast, much of the research on young adults' financial outcomes focuses on their transition to adulthood, involving costly investments in human capital, increased financial responsibility, and independence from parental support. Table 1 summarises the outcomes that have been considered for each group.

This article is protected by copyright. All rights reserved. 
Transaction and savings accounts

Studies have found that most adolescents hold bank accounts and that young adults are even more likely to hold accounts (Elliott, 2012; Friedline et al., 2011; Friedline, 2012; Kim et al., 2016). In Australia, bank account holding among young adults is nearly universal, as welfare system payments managed by the Department of Human Services (DHS) are often deposited directly into bank accounts (DHS, 2019). However, financial access is a substantial concern in the United States, with many young adults being “unbanked” (Elliott, 2012).

Although adolescents commonly hold bank and savings accounts, the balances in those accounts tend to be modest (Elliott, 2012; Friedline, 2012; Loke et al., 2015). Low account balances frequently persist into young adulthood because of schooling and large non-discretionary expenses (Elliott, 2012; Friedline et al., 2011; Elliott 2012; Lobaugh, Stephens, and Simpson, 2019). Adolescents appear to make their savings decisions in the same way as adults, with considerations of trade-offs between present and future outcomes and with the development of more conservative risk preferences and precautionary motivations (Friedline, 2015; Otto, 2013; Sutter et al., 2018). Research has linked adolescent and young adult savings behaviour to earlier experiences with savings (Elliott 2012), parents’ savings behaviour (Friedline, 2012), family socialisation (Angulo-Ruiz and Pergelova, 2015; Drever et al., 2015; Kim et al., 2015), financial knowledge (Angulo-Ruiz and Pergelova, 2015; Loke et al., 2015), and other characteristics.

\section{Debt and borrowing}

Because of the legal restrictions on minors taking on debt, debt and borrowing among adolescents is only infrequently studied. Seuntjens et al. (2016) examined

This article is protected by copyright. All rights reserved. 
informal debts among adolescents; a review of research on adolescents' and young adults’ debt by Hoeve et al. (2014) lists eight other studies. The incidence, level, and management of debt among young adults is, however, an area of more concern. Houle (2014) documents how debt burdens, especially for education loans, have increased across generations of young adults in the United States. Houle also describes how mortgage debt—and consequently home ownership—has fallen. Brown et al. (2015), Kim et al. (2012), and Shim et al. (2009) investigate how household circumstances, financial socialisation, and financial literacy programs affect debt outcomes.

\section{Expenses}

A related area of financial concern involves nondiscretionary expenses, such as education and housing costs. Lobaugh, Stephens, and Simpson (2019) and Hoeve et al. (2014) document that these have risen significantly among young adults, driven in large part by spending and borrowing for education and by credit card expenses. For Australia, Wood, Griffiths, and Emslie (2019) show that young adults’ overall spending has remained relatively flat over time, even as spending by older adults has grown; they also note that nondiscretionary expenses have crowded out discretionary purchases.

\section{Net wealth}

With rising nondiscretionary expenses and higher debt levels, net wealth has fallen for recent cohorts of young people. Lobaugh et al. (2019) report that net wealth has declined for successive cohorts of young Americans, and Wood et al. (2019) report similar trends for young Australians. Houle (2014) finds that the proportion of young Americans with negative net worth has doubled across the last three generations.

This article is protected by copyright. All rights reserved. 


\section{Hardships and deprivations}

Higher costs and reduced resources also put young people at risk of experiencing hardships and deprivations. Studies on hardships in adolescence tend to be measured at the household level, reflecting parents' major influence on adolescents’ financial outcomes (Harding and Szukalska 2000; Ralston et al. 2017, AIHW 2018). Research on young adults tends to differ however, as the process of moving out and becoming financially independent of parental support can involve personal experiences of hardship (Cobb-Clark and Ribar 2012; Ribar 2015; Shim et al. 2009). Ryan (2014) provides evidence that Australian university students experience more hardships than non-students. Shim et al. (2009) also show that large student-debt burdens in the United States contribute to extreme coping behaviours such as the use of payday loans, postponement of medical or dental care, and use of credit cards to pay off debt. Housing insecurity and homelessness among adolescents and young adults is also a significant research area, as young people comprise a significant proportion of the homeless population (ABS 2018; Mallett, Rosenthal, and Keys, 2005; McNamara 2015; van den Bree et al. 2009).

\section{Financial management}

Financial management behaviours, such as balancing spending and savings, controlling spending, paying bills, budgeting and planning, and tracking finances, are conducive to good financial outcomes. Many studies, including Jorgensen et al. (2017), Ryan (2014), and Shim et al. (2009) have examined these outcomes in young adults. Because of the limits on their responsibilities and autonomy, fewer financial management behaviours are examined among adolescents. For example, Loke et al. (2015) examine a financial education intervention that improved adolescents' rates of tracking spending, budgeting, evaluating needs versus wants in making spending 
decisions, and saving. Drever et al. (2015) and Sutter et al. (2018) summarise evidence regarding adolescents’ developmental capabilities for making financial management decisions.

Financial autonomy and independence

The scope for financial and other types of decision-making increases during adolescence. Bumpus et al. (2001) investigate personal and household characteristics that lead to increases in children’s and adolescents’ autonomy. Lundberg et al. (2009) also examine the determinants of adolescent autonomy and conceptualise it as noncooperative game in the household between parents and children. As part of the transition to adulthood, young people attain financial and residential independence, where they have primary responsibility for their financial and housing situations. Cobb-Clark and Gørgens (2014), Cobb-Clark and Ribar (2012), and Ribar (2015) have investigated the antecedents and outcomes associated with these transitions.

\section{Superannuation}

Superannuation lays a foundation for long-term financial security, though contributions and accumulations tend to be small early in adulthood. Although many adolescents take on work opportunities and some of these arrangements involve superannuation, very little academic attention has been given to their superannuation or retirement savings. More research has considered these outcomes for young adults. Ali et al. (2015) document low levels of knowledge about superannuation among young adults which contribute to low levels of engagement. Parrish and Delpachitra (2012) show that better information prompts could affect fund selection.

\section{Financial satisfaction and anxiety}

People’s subjective summation of their financial condition can be measured

This article is protected by copyright. All rights reserved. 
positively through measures of financial satisfaction and negatively through measures of financial anxiety. Because of their limited financial burdens and responsibilities, adolescents have not been studied much. However, Kim et al. (2011) report that adolescents can feel financial anxiety about their and their family’s economic circumstances, with $18 \%$ of adolescents in the United States responding by contributing money towards family expenditures. Ribar (2015), Ryan (2014), and Shim et al. (2009) have examined financial satisfaction among young adults and document how satisfaction generally improves with economic attainments but can diminish with critical transitions, such as nest-leaving.

\section{Financial wellbeing}

Financial wellbeing is a comprehensive concept that incorporates many components of people's financial outcomes. These include temporal components that involve people's present financial situations, their future aspirational outcomes, and outcomes under uncertain and possibly adverse circumstances. They also involve functional components that allow people to meet obligations and responsibilities, enjoy extra consumption, and feel secure and in control of their finances. To our knowledge, financial wellbeing has not been directly examined among adolescents. Shim et al. (2009) estimate a comprehensive structural equations model of the contextual and behavioural determinants of young adults' financial wellbeing and of the effect of financial wellbeing on other domains of wellbeing. Sorgente and Lanz (2017) summarise results from other studies that have examined young adults’ financial wellbeing. 


\section{Data}

We consider the structure and financial content in three large longitudinal Australian surveys which include adolescents, young adults, or both as subjects. These surveys are the Longitudinal Surveys of Australian Youth, the Longitudinal Study of Australian Children, and the Household, Income and Labour Dynamics in Australia Survey. Table 2 provides a comparative overview of the three surveys' structures.

The surveys focus on different populations. The subjects in the LSAY are adolescents when they are first interviewed, and the LSAY follows them in annual individual interviews into young adulthood. The focal subjects in the LSAC were two cohorts of children who were either 0-1 years old (the Birth Cohort) or 4-5 years old (the Kindergarten Cohort) when the survey began in 2003. They have been followed in biennial multi-informant interviews since then, with the most recent available data being collected in 2017, when the Birth-Cohort children were aged $12-13$ years old and Kindergarten-Cohort children were $16-17$ years old. In contrast to these cohort surveys, the HILDA Survey is a general household panel that interviews all individuals in a given household who are age 15 or older. Thus, the HILDA Survey includes adolescents and young adults.

Because of their subject populations, the surveys differ in the measures they collect. The measures in the LSAY and LSAC focus on child, adolescent, and young adult outcomes and change as the subjects age. The measures in the HILDA Survey are oriented strongly towards adults and are relatively stable over the course of the survey. Table 3 provides an overview of the coverage of indicators for financial

This article is protected by copyright. All rights reserved. 
outcomes in the three surveys. We discuss the structure and content of the individual surveys in more detail below.

\section{The Longitudinal Surveys of Australian Youth}

The LSAY follows cohorts (beginning from 1995, 1998, 2003, 2006, 2009, and 2015) of young Australians annually over a ten-year period, from their mid-teens to mid-twenties, as they move through school to further study, work and beyond. The LSAY obtains its information through individual interviews with adolescents and young adults; the subjects report about their own outcomes and their households.

The LSAY collects relatively few financial indicators, and the coverage of issues is limited in scope. Respondents' satisfaction with their living standards has been collected since about age 16 or 17 years for most cohorts. Questions about experiences with saving and the repayment of credit card debt and respondents' overall sense of how they are managing financially are asked from age 18 onwards. Questions about experiences of hardship/deprivation were asked starting at about age 18 years for the 1998 Cohort and starting at ages $19-20$ for other cohorts. Once introduced for a cohort, these financial outcomes are collected consistently until respondents reach age 25 years.

Several questions in the LSAY, including those about respondents' savings and credit card behaviour, only allow for qualitative responses, such as whether people are unable to save, save "only occasionally", or save "fairly regularly". The LSAY unfortunately lacks other important information, such as the possession or balances of savings accounts and many other financial outcomes.

This article is protected by copyright. All rights reserved. 
In addition to the financial variables, the LSAY collects information on living arrangements and whether people are accumulating HECS debts while studying, issues that have been studied in the international financial outcomes literature. The latter seems less of an issue in Australia than in many other countries, given the uniform annual debt amounts across institutions and the contingent repayment arrangements, involving deferred repayments through the income tax system.

Given the ages of respondents, the LSAY is a valuable resource for studying some outcomes in late adolescence and emerging adulthood, but nonetheless has limitations due to the lack of detailed or extensive information on financial outcomes and behaviours.

\section{The Longitudinal Study of Australian Children}

The LSAC is a multi-informant survey that has been following two cohorts of Australian children and their families every two years since 2003. Each wave of the LSAC includes assessments or interviews with the focal children and interviews with their parents, caregivers, and teachers. For the purposes of this article, we focus on questions that are asked of the focal children starting at age 16.

The LSAC contains information on household context, including the financial outcomes of the young person's parents that may affect the household's experience of poverty, financial hardships, and deprivation. These measures for the parents are available for the period from childhood through to emerging adulthood for the young person. There is no information about the possession of savings accounts, either on behalf of the child or in the child's own right until the young person answers such questions themselves at age 16 to 17 years.

This article is protected by copyright. All rights reserved. 
From age 16 to 17 onwards, the LSAC asks about young people's incomes, their personal experiences of financial hardship and deprivation, their ability to save, and their possession of different types of savings and credit accounts. Further, there are detailed, overlapping questions asked of parents and children the about the provision of financial support to the young person at age 16 to 17 . These are the only questions that provide actual magnitudes of financial support in the survey. Unfortunately, in the following wave these questions were only asked of young people (and not of parents), and did not measure the magnitude of financial support.

Compared to LSAY, the range of potential studies using LSAC data is more extensive, covering child, adolescent and emerging adult outcomes. The LSAC supports study of the incidence of deprivation experiences, both for individual items and for aggregated measures for households across age groups. It is also possible to look at financial accounts held across adolescence and emerging adulthood, as well as financial management of accounts and moves towards financial independence among emerging adults. Notably, there are numerous developmental indicators and personality-related measures collected about young people which would potentially provide a richer picture of the individual factors associated with the young person's financial outcomes than is typically available in other studies.

In summary, the scope for studying young people's financial outcomes with LSAC data is greater than for LSAY and the possibilities will improve in future waves.

The Household, Income and Labour Dynamics in Australia Survey The HILDA Survey is a nationally representative longitudinal survey that This article is protected by copyright. All rights reserved. 
began with 19,914 people in 7,682 Australian households in 2001 . The survey is collected on a yearly basis and currently covers more than 18,000 Australians in 2017.

Each year the HILDA Survey asks comprehensive questions about employment, wages and salaries and their components, incomes, household circumstances, and other outcomes for all household members ages 15 and older in each surveyed household. It asks some other questions, such as questions about wealth and assets, less frequently. The domains of questions in the HILDA Survey focusing on financial outcomes can be grouped by when and how frequently they are asked:

- Usually Every Year: Decision making in household; Attitudes to finances; Housing; Household expenditure; Major life events; Child Support; Wage and salaries; and Household expenditure.

- During HILDA Wealth Module Years (2002, 2006, 2010, 2014, etc.): Bank accounts; Business; Credit cards; Personal debt; Financial assets; Household bills; Household wealth; Motor vehicles; and Personal wealth.

- One-off focus year in 2014: Material deprivation.

This periodicity can be seen clearly in Table 4, which outlines the availability of the components and the years in which they are available. Information on household financial decision making is available yearly or biennially. Information on attitudes and behaviours with respect to financial matters is available most years. A battery of questions dealing with financial hardships is asked yearly, such as having to pawn or sell items to cover financial needs, going without meals, or asking for financial help

This article is protected by copyright. All rights reserved. 
from friends and family. To address financial planning and reserves, respondents are asked how they would immediately raise $\$ 2,000-\$ 3,000$ for unexpected financial needs. Respondents are explicitly asked about their financial risk preferences on a four-point scale. Household annual expenditures on broad categories of goods and services such as alcohol, cigarettes, meals eaten out, and groceries are available every year since 2006. These indicators give insights into financial decision making with respect to immediate consumption and longer-term planning. A battery of questions concerning major life events also tracks major financial improvement and worsening each year. People's subjective wellbeing indicators for their lives in general and their financial situation provide overview information of the person or household's financial situation. Especially when large year-on-year changes are experienced, whether positive or negative, this can provide valuable insight into financial dynamics and triggers. Given the high rate of marital dissolution, the transfer of resources from a non-custodial parent to a custodial parent can be key to identifying the resources available to children, adolescents and emerging adults. This information is available for most years.

Detailed bank account information is collected from adolescents and emerging adults responding to the quadrennial wealth modules. Also, parents are asked for bank account information for children in the household, if applicable. Detailed information on credit card possession and balance payments is also part of the wealth module, but general information on having credit cards is available yearly since 2012. Details of personal debt are asked. Of particular relevance to emerging adults is information of higher education related debt such as HECS debt and debt

This article is protected by copyright. All rights reserved. 
related to cars. Unpaid debt is explicitly asked about, as is the amount of unpaid debt.

In 2014, a very detailed one-off battery of material deprivations was asked, including 70 items. The battery aimed to identify the extent to which household or personal income information is insufficient to provide insight into people who are unable to take part in society in a "normal" manner.

A strength of the HILDA Survey is an extensive set of financial outcomes, many of which are available in every year of the survey. The HILDA follows and individually interviews subjects from age 15 on, providing measures through adolescence, young adulthood, and beyond. The HILDA Survey can describe individual outcomes within households while the young people are still living with parents. It also has information about parents after young people move out on their own, allowing researchers to examine inter-household linkages and transfers.

\section{Discussion}

Amidst concerns across developed countries that young people face increasingly fraught transitions to adulthood in many dimensions, it is important that their financial circumstances receive the attention they warrant among competing areas of concern (Lobaugh, Stephens, and Simpson, 2019; Wood, Griffiths, and Emslie, 2019). Thankfully, existing Australian social surveys include information that facilitates research on the financial outcomes of young people, among many other topics. Nevertheless, the coverage and content of these surveys, as they measure financial outcomes, could be improved.

This article is protected by copyright. All rights reserved. 
All three Australian social surveys studied here - LSAY, LSAC and HILDA elicit personal information from young people from mid-adolescence onwards. Importantly, this covers a period in which individuals gain more control of financial outcomes (Lundberg, Romich, and Tsang, 2009) and face greater financial responsibilities. All three surveys collect information on the hardships/deprivations young people potentially face, which enables studies to be undertaken on how young people cope with binding financial constraints. Further, the three surveys all collect information on young people's receipt of government benefits (such as Youth Allowance), such that evaluations of the receipt of welfare payments on the financial outcomes and wellbeing of young people are possible.

Each of the surveys has strengths, but also limitations for the study of financial outcomes among young people. LSAY can be used to examine relatively few financial outcomes - satisfaction with finances, experiences of deprivations, saving behaviour and credit card usage. However, it facilitates research on early millennial cohorts not covered in the other surveys and allows comparisons across cohorts.

Likewise, the LSAC survey currently has few person-specific financial outcome measures - from age 16 onwards, the LSAC asks about young people's experience of deprivations, possession of financial accounts, uses of money, and ability to save. However, these are more extensive than the LSAY.

The most comprehensive source of information on young people's financial outcomes is the HILDA survey. HILDA's survey structure and robust set of questions seem to be particularly suited to research on young Australians' financial outcomes, providing objective information on personal net wealth, including account balances, This article is protected by copyright. All rights reserved. 
debts (including educational loans), and overdue bills. In addition, the multiinformant design richly depicts the household context and allows comparisons between young people's outcomes and their parents' outcomes, including subjective perceptions of individual and household finances. The panel structure of the data encourages thinking about the evolution of states and experiences among young people as they age and are affected by external phenomena.

In general, the three social surveys make it possible to undertake studies of young people's financial outcomes like those highlighted in Table 1, including studies of savings behaviours, financial satisfaction, the experience of hardship and deprivation, and of financial independence. Particularly fruitful directions for research that uses the HILDA survey include: when young people approach financial independence and the factors that shape that transition, along with how the transition process might be changing; how government transfers affect/mitigate experiences of specific hardships/deprivations among young people; their accrual of and repayment of debt, including credit card and HECS debt; their contributions to and engagement with superannuation; and savings behaviours and possession of other financial assets/investments.

This article is protected by copyright. All rights reserved. 


Financial outcome Study Subjects

\begin{tabular}{|c|c|c|}
\hline $\begin{array}{l}\text { Banking and } \\
\text { savings }\end{array}$ & $\begin{array}{l}\text { Angulo-Ruiz \& Pergelova } \\
\text { (2015) }\end{array}$ & Adolescents \& young adults \\
\hline & *Elliott (2012) & Adolescents \& young adults \\
\hline & Friedline et al. (2011) & Adolescents \& young adults \\
\hline & Friedline (2012) & Adolescents \\
\hline & Kim et al. (2011) & Adolescents \\
\hline & Kim et al. (2016) & Adolescents \& young adults \\
\hline & Loke et al. (2015) & Adolescents \\
\hline & *Otto (2013) & Adolescents \\
\hline & Seuntjens et al. (2016) & Adolescents \\
\hline & *Sutter et al. (2018) & Adolescents \\
\hline Debt and & Brown et al. (2015) & Young adults \\
\hline & Hoeve et al. (2014) & Adolescents \& young adults \\
\hline & Houle (2014) & Young adults \\
\hline & Kim et al. (2012) & Young adults \\
\hline
\end{tabular}

This article is protected by copyright. All rights reserved. 
Seuntjens et al. (2016)

Shim et al. (2009)

Expenses

Lobaugh et al. (2019)

Seuntjens et al. (2016)

Wood et al. (2019)

Net wealth

Houle et al. (2019)

Lobaugh et al. (2019)

Wood et al. (2019)

Hardships and deprivations

ABS (2018)

Cobb-Clark and Ribar (2012)

Harding and Szukalska (2000)

Mallett et al. (2005)

*McNamara (2015)

Ralston et al. (2017)

Ribar (2015)
Adolescents

Young adults

Young adults

Adolescents

Young adults

Young adults

Young adults

Young adults

Adolescents \& young adults

Adolescents \& young adults

Adolescents

Adolescents \& young adults

Adolescents \& young adults

Adolescents

Young adults

This article is protected by copyright. All rights reserved. 
Shim et al. (2009)

van den Bree et al. (2009)

*Drever et al. 2015

Financial

management

Jorgensen et al. (2017)

Loke et al. (2015)

Ryan (2014)

Shim et al. (2009)

*Sutter and Glätzle-Rützler (2018)

Financial

autonomy and independence from parents
Bumpus et al. (2001)

Cobb-Clark and Gørgens (2014) Young adults

Cobb-Clark and Ribar (2012)

Lundberg et al. (2009)

Ribar (2015)

Ali et al. (2015)

Parrish and Delpachitra (2012)

Young adults
Young adults

Adolescents \& young adults

Adolescents \& young adults

Young adults

Adolescents

Young adults

Young adults

Adolescents
Adolescents

Adolescents \& young adults

Adolescents

Young adults

Young adults

Superannuation

This article is protected by copyright. All rights reserved. 
Financial satisfaction and anxiety

anxiety

Kim et al. (2011)

Ribar (2015)

Ryan (2014)

Shim et al. (2009)
Adolescents

Young adults

Young adults

Young adults

Young adults

wellbeing
Shim et al. (2009)

*Sorgente and Lanz (2017)
Young adults

Notes: Studies marked with asterisks $(*)$ are reviews or meta-analyses.

Table 2 Structure Overview of LSAY, LSAC and HILDA Survey

\begin{tabular}{|c|c|c|c|}
\hline & LSAY & $\angle S A C$ & $\begin{array}{l}\text { HILDA } \\
\text { Survey }\end{array}$ \\
\hline $\begin{array}{l}\text { Type of } \\
\text { Survey }\end{array}$ & $\begin{array}{l}\text { Six cohorts of young } \\
\text { Australians, mid- } \\
\text { teens to mid- } \\
\text { twenties, as they } \\
\text { move through } \\
\text { school, study, work } \\
\text { and beyond }\end{array}$ & $\begin{array}{l}\text { Multi-informant } \\
\text { survey (child, parent, } \\
\text { teacher, } \\
\text { administrative health, } \\
\text { education and } \\
\text { government welfare } \\
\text { information) that has } \\
\text { followed the families } \\
\text { of two cohorts of } \\
\text { Australian children }\end{array}$ & $\begin{array}{l}\text { National longitudinal, } \\
\text { all adults, yearly, } \\
\text { following household } \\
\text { members in household } \\
\text { splits }\end{array}$ \\
\hline
\end{tabular}

This article is protected by copyright. All rights reserved. 


\begin{tabular}{|c|c|c|c|}
\hline Sample Size & $\begin{array}{l}\text { First cohort approx. } \\
14,000 \text { Year } 9 \\
\text { students in } 1995 \\
\text { who were followed } \\
\text { until } 2006 . \text { Later } \\
\text { cohorts in } 1998, \\
2003,2006,2009 \\
\text { and } 2015 \text { with } \\
\text { similar numbers }\end{array}$ & $\begin{array}{l}\text { Around } 5,000 \\
\text { children in each } \\
\text { cohort: Baby cohort } \\
\text { \& Kindergarten } \\
\text { cohort }\end{array}$ & $\begin{array}{l}\text { 9,914 people in } \\
\text { 7,682 Australian } \\
\text { households in } \\
\text { 2001. Currently } \\
\text { approximately } \\
18,000 \text { persons. }\end{array}$ \\
\hline Period & $\begin{array}{l}\text { Followed annually, } \\
\text { ten-year period, first } \\
\text { cohort 1995-2006; } \\
\text {...; last cohort 2015- } \\
20 X X\end{array}$ & $\begin{array}{l}\text { Every two years since } \\
2003, \text { when B \& K } \\
\text { cohorts were aged 4- } \\
5 \text { (Kindergarten } \\
\text { cohort) years and 0-1 } \\
\text { year (Baby cohort) } \\
\text { respectively }\end{array}$ & $\begin{array}{l}\text { Yearly since 2001. Currently } \\
2017 .\end{array}$ \\
\hline $\begin{array}{l}\text { Primary } \\
\text { Respondent }\end{array}$ & $\begin{array}{l}\text { Young adults, } \\
\text { mid-teens to } \\
\text { mid-twenties }\end{array}$ & $\begin{array}{l}\text { When children are } \\
\text { younger, primary } \\
\text { respondents are } \\
\text { parents. As children } \\
\text { reach 18, survey } \\
\text { focus shifts to child } \\
\text { directly. }\end{array}$ & $\begin{array}{l}\text { All adults in household } 15 \\
\text { and over }\end{array}$ \\
\hline Domains & $\begin{array}{l}\text { Initial schooling- } \\
\text { based focus; } \\
\text { achievement tests. } \\
\text { Experience of } \\
\text { schooling, transition } \\
\text { through further } \\
\text { education and } \\
\text { training into the } \\
\text { world of work, } \\
\text { income, housing, } \\
\text { family formation, } \\
\text { and adulthood }\end{array}$ & $\begin{array}{l}\text { Family economic } \\
\text { circumstances, } \\
\text { parental living } \\
\text { arrangements, } \\
\text { siblings, maternal and } \\
\text { child health, school } \\
\text { environment, and } \\
\text { many cognitive and } \\
\text { other developmental } \\
\text { outcomes. }\end{array}$ & $\begin{array}{l}\text { Family life, economic } \\
\text { wellbeing, the labour } \\
\text { market, employment, self- } \\
\text { employment, education, and } \\
\text { cognitive abilities, transition } \\
\text { through further education } \\
\text { and training into the world of } \\
\text { work, income, housing, } \\
\text { family formation, and } \\
\text { adulthood }\end{array}$ \\
\hline $\begin{array}{l}\text { Detailed } \\
\text { documentation }\end{array}$ & $\begin{array}{l}\text { Parvazian and Semo } \\
\text { (2018), NCVER } \\
\text { (2019) }\end{array}$ & AIFS $(2017,2019)$ & Summerfield et al. (2019) \\
\hline
\end{tabular}

This article is protected by copyright. All rights reserved. 
Table 3 Coverage of Financial Outcomes in Australian Longitudinal Data Sets

\begin{tabular}{|c|c|c|c|c|c|c|}
\hline \multirow[b]{2}{*}{ Financial outcome } & \multicolumn{2}{|c|}{$L S A Y$} & \multicolumn{2}{|c|}{ LSAC } & \multicolumn{2}{|c|}{ HILDA Survey } \\
\hline & $\begin{array}{l}\text { Young } \\
\text { Person }\end{array}$ & Parents & $\begin{array}{l}\text { Young } \\
\text { Person }\end{array}$ & Parents & $\begin{array}{l}\text { Young } \\
\text { Person }\end{array}$ & Parents \\
\hline $\begin{array}{l}\text { Possession of bank } \\
\text { accounts }\end{array}$ & - & - & $16-19$ & - & $15+$ & Both \\
\hline $\begin{array}{l}\text { Ability/Habits in } \\
\text { saving money }\end{array}$ & $18-25$ & - & $16-19$ & - & $15+$ & Self \\
\hline Income/Earnings & $15-25$ & 一 & $16-19$ & Self & $15+$ & Self \\
\hline $\begin{array}{l}\text { Receipt of government } \\
\text { benefits }\end{array}$ & $16-25$ & 一 & $16-19$ & Self & $15^{+}$ & Self \\
\hline $\begin{array}{l}\text { Allowance/Pocket } \\
\text { money }\end{array}$ & - & - & $16-17$ & Child & $15+$ & Child \\
\hline $\begin{array}{l}\text { Family financial } \\
\text { support }\end{array}$ & - & 一 & $16-19$ & Child & $15+$ & Self \\
\hline $\begin{array}{l}\text { Receipt of child } \\
\text { support }\end{array}$ & - & - & & Self & - & Self \\
\hline $\begin{array}{l}\text { Decision-making } \\
\text { responsibilities }\end{array}$ & - & - & - & - & $15+$ & Self \\
\hline $\begin{array}{l}\text { Ability to raise } \\
\text { emergency money }\end{array}$ & - & - & - & Self & $15+$ & Self \\
\hline $\begin{array}{l}\text { Hardship/Deprivation } \\
\text { experiences }\end{array}$ & $18-25$ & - & $16-19$ & Self & $15+$ & Both \\
\hline Financial satisfaction & $16-25$ & - & - & - & $15+$ & Self \\
\hline
\end{tabular}

This article is protected by copyright. All rights reserved. 


\begin{tabular}{|c|c|c|c|c|c|c|}
\hline Credit cards & $18-25$ & - & $16-19$ & - & $15+$ & Self \\
\hline Personal debt & - & - & $18-19$ & - & $15^{+}$ & Self \\
\hline Expenses & - & - & $16-19$ & Child & - & Household \\
\hline Major life events & - & - & - & - & $15^{+}$ & Self \\
\hline Financial attitudes & - & - & $16-19$ & - & $15+$ & Self \\
\hline Financial literacy $^{\mathrm{a}}$ & - & - & - & - & $15+$ & Self \\
\hline $\begin{array}{l}\text { Assets and } \\
\text { investments }\end{array}$ & - & - & - & - & - & Household \\
\hline $\begin{array}{l}\text { Motor vehicle } \\
\text { ownership }\end{array}$ & - & - & - & 一 & - & Household \\
\hline Business ownership & - & - & - & - & - & Household \\
\hline $\begin{array}{l}\text { Plans to buy } \\
\text { residential property }\end{array}$ & - & - & - & - & $15-29$ & - \\
\hline Superannuation & - & - & - & - & $15+$ & Self \\
\hline
\end{tabular}

Notes: The "Young Person” columns indicate each outcomes' age coverage in their respective surveys. The "Parents" columns indicate if the measure is asked about the parents themselves (Self), about the young person (Child), about both parents and the young person (Both), or about the household in general (Household).

a. Questions about financial literacy are collected once during Wave 16 of the HILDA Survey. Financial literacy was also measured in the first wave of the 2015 LSAY cohort, but not in previous cohorts.

b. Questions about young people's financial plans and preparations to purchase property are collected once during Wave 4 of the HILDA Survey.

This article is protected by copyright. All rights reserved. 
Table 4 Financial Outcome Measures in Waves 1-17 of the HILDA Survey

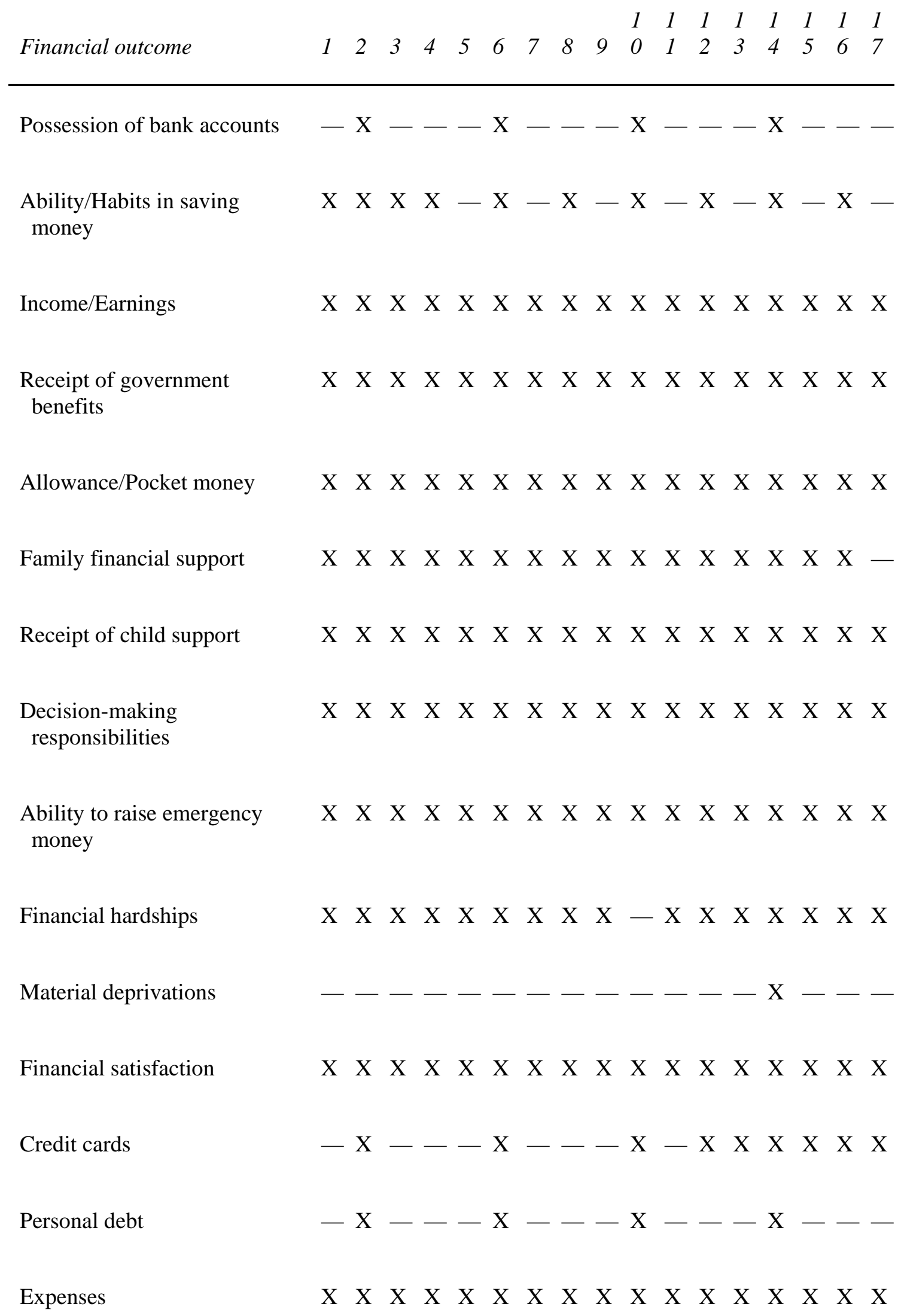


Major life events

Financial attitudes

Financial literacy

Assets and investments

Motor vehicle ownership

Business ownership

Plans to buy residential property

Superannuation
$\begin{array}{lllllllllllllllll}X & X & X & X & X & X & X & X & X & X & X & X & X & X & X & X & X\end{array}$
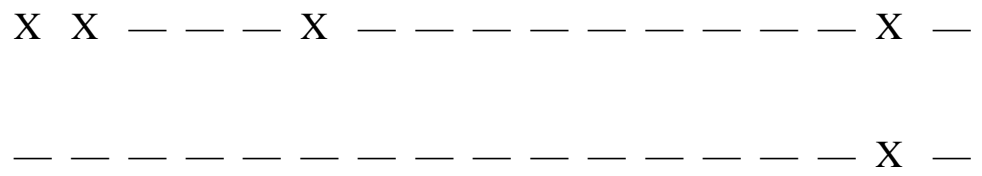

$-X-1-X-1-X-1-$

$\mathrm{X} \quad \mathrm{X}-\mathrm{-}-\mathrm{X}--\mathrm{X}--\mathrm{X}--$

$-\mathrm{X}--\mathrm{X}-\mathrm{X}-\mathrm{X}--\mathrm{X}--$

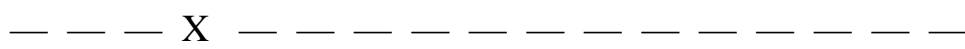

$-X--x-1-X-1-\cdots$

Notes: " $\mathrm{X}$ " indicates that the measure is available in the indicated wave; "_." indicates that the measure is not available in the wave. See Hahn and Haisken-DeNew (2013).

\section{References}

Ali, P., Anderson, M., Clark, M., Ramsay, I. and Shekhar, C. 2015, 'No thought for tomorrow: young Australian adults' knowledge, behaviour and attitudes about superannuation’ Law and Financial Markets Review, vol. 9, pp. 90-105.

Angulo-Ruiz, F. and Pergelova, A. 2015, 'An Empowerment Model of Youth Financial Behavior’, Journal of Consumer Affairs, vol. 49, pp. 550-75.

Australian Bureau of Statistics 2018, Census of Population and Housing: Estimating homelessness, 2016, Cat. No. 2049.0, ABS, Canberra.

Australian Institute for Family Studies [AIFS]. (2017) "Chapter 1: Introduction and overview of LSAC data" in LSAC Annual Statistical Report 2016, Vol 7.

Australian Institute for Family Studies 2019, Longitudinal Study of Australian Children Data dictionary Release 7.0, Waves 1-7, AIFS, Melbourne, viewed July 2019, < https://growingupinaustralia.gov.au/data-anddocumentation/data-dictionary/downloads $>$.

Australian Institute of Health and Welfare 2019, Children's Headline Indicators, AIHW, Canberra: AIHW, viewed June 2019

This article is protected by copyright. All rights reserved. 
$<$ https://www.aihw.gov.au/reports/children-youth/childrens-headlineindicators $>$.

Brown, M., Grigsby, J., van der Klaauw, W., Wen, J. and Zafar, B. 2015, 'Financial Education and the Debt Behavior of the Young', Federal Reserve Bank of New York Staff Report no. 634, New York.

Bumpus, M., Crouter, A. and McHale, S. 2001, 'Parental Autonomy Granting During Adolescence: Exploring Gender Differences in Context', Developmental Psychology, vol. 37, pp. 163-73.

Cobb-Clark, D. and Gørgens, T. 2014, 'Parents’ Economic Support of Young-Adult Children: Do Socioeconomic Circumstances Matter?’, Journal of Population Economics, vol. 27, pp. 447-71.

Cobb-Clark, D. and Ribar, D. C. 2012, 'Financial stress, family relationships, and Australian youths' transitions from home and school', Review of Economics of the Household, vol. 10, pp. 469-90.

Department of Human Services 2019, A guide to Australian Government payments, 1 July-19 September 2019, DHS, Canberra: DHS.

Drever, A., Odders-White, E., Kalish, C., Else-Quest, N., Hoagland, E. and Nelms, E. 2015, 'Foundations of Financial Well-Being: Insights into the Role of Executive Function, Financial Socialization, and Experience-Based Learning in Childhood and Youth', Journal of Consumer Affairs, vol. 49, pp. 13-38.

Elliott, W. 2012, Does Structural Inequality Begin with a Bank Account?, Creating a Financial Stake in College Report no. II, Washington University, St. Louis, Missouri.

Friedline, T. 2015, 'A Developmental Perspective on Children’s Economic Agency.' Journal of Consumer Affairs 49:1 (Spring), 39-68.

Friedline, T. 2012, 'Predicting Children's Savings: The Role of Parents’ Savings for Transferring Financial Advantage and Opportunities for Financial Inclusion', Children and Youth Services Review, vol. 34, pp. 144-54.

Friedline, T., Elliott, W. and Nam, I. 2011, 'Predicting Savings from Adolescence to Young Adulthood: A Propensity Score Approach', Journal of the Society for Social Work and Research, vol. 2, pp. 1-22.

Gudmunson, C. and Danes, S. 2011, 'Family Financial Socialization: Theory and Critical Review', Journal of Family and Economic Issues, vol. 32, pp. 644-67.

Hahn, MH. and Haisken-DeNew, JP. 2013, 'PanelWhiz and the Australian Longitudinal Data Infrastructure in Economics', Australian Economic Review, 46(3), 1-8.

Haisken-DeNew, J., Ribar, D. C., Ryan, C. and Wong, C. 2019, A Conceptual Framework to Measure Young Australians’ Financial Wellbeing,

This article is protected by copyright. All rights reserved. 
Commonwealth Bank of Australia and Melbourne Institute Financial Wellbeing Scales Technical Report No. 4, University of Melbourne.

Harding, A. and Szukalska, A. 2000, 'Trends in Child Poverty in Australia, 1982 to 1995-96', The Economic Record, vol. 76, pp. 236-54.

Hoeve, M., Stams, G., van der Zouwen, M., Vergeer, M., Jurrius, K. and Asscher, J. 2014, 'A Systematic Review of Financial Debt in Adolescents and Young Adults: Prevalence, Correlates and Associations with Crime', Plos ONE, vol. 9, no. 8, article e104909.

Houle, J. 2014, 'A Generation Indebted: Young Adult Debt across Three Cohorts', Social Problems, vol. 61, pp. 448-65.

Jorgensen, B., Rappleyea, D., Schweicher, J., Fang, X. and Moran, M. 2017, 'The Financial Behavior of Emerging Adults: A Family Financial Socialization Approach', Journal of Family Issues, vol. 38, pp. 57-69.

Kim, J., Chatterjee, S. and Kim. J. 2012, 'Debt Burden of Young Adults in the United States', Journal of Financial Counseling and Planning, vol. 23, pp. 55-67.

Kim, J., Kim, J. and Moon, U. 2016, 'Differences in Bank Account Ownership among White, Black, and Latino Children and Young Adults', Journal of Financial Counseling and Planning, vol. 27, pp. 212-30.

Kim, J., LaTaillade, J. and Kim, H. 2011, 'Family Processes and Adolescents' Financial Behaviors', Journal of Family and Economic Issues, vol. 32, pp. 668-79.

Lobaugh, K., Stephens, B. and Simpson, J. Deloitte 2019, Insights: The Consumer is Changing But Perhaps Not How You Think, Deloitte Center for Consumer Insight, Kansas City, Missouri.

Loke, V., Choi, L. and Libby, M. 2015, 'Increasing Youth Financial Capability: An Evaluation of the MyPath Savings Initiative', Journal of Consumer Affairs, vol. 49, pp. 97-126.

Lundberg, S., Romich, J. and Tsang, K. 2009, 'Decision-making by children', Review of Economics of the Household, vol. 7, pp. 1-30.

Mallett, S., Rosenthal, D. and Keys, D. 2005, 'Young people, drug use and family conflict: Pathways into homelessness', Journal of Adolescence, vol. 28, pp. 185-99.

McNamara, P. 2015, 'Young People at Risk of Lifelong Poverty: Youth Homelessness in Australia', in Theoretical and Empirical Insights into Child and Family Poverty. Children's Well-being: Indicators and Research, eds E. Fernandez, A. Zeira, T. Vecchiato and C. Canali, Springer, London.

National Centre for Vocational Education Research, 2019, LSAY variable listing and metadata, NCVER, Adelaide, viewed July 2019 $<$ https://www.lsay.edu.au/publications/search-for-lsay-publications/2621>.

This article is protected by copyright. All rights reserved. 
Otto, A. 2013, 'Saving in childhood and adolescence: Insights from developmental psychology', Economics of Education Review, vol. 33, pp. 8-18.

Parrish, T. and Delpachitra, S. 2012, 'On Selection of Superannuation Fund: Impact of Choice and Information’, Economic Papers, vol. 31, pp. 369-79.

Parvazian, S. and Semo, R. 2018, 'The Longitudinal Surveys of Australian Youth: 20 Years and Beyond', Australian Economic Review, vol. 51, pp. 426-40.

Ralston, K., Treen, K., Coleman-Jensen, A. and Guthrie, J. 2017, Children's Food Security and USDA Child Nutrition Programs, Economic Research Service Report no. EIB-174, U.S. Department of Agriculture, Washington.

Ribar, D. C. 2015, 'Is Leaving Home a Hardship?’, Southern Economic Journal, vol. 81, pp. 598-618.

Ryan, C. 2014, 'Youth Allowance and the Financial Position of Young Australians', Australian Economic Review, vol. 47, pp. 115-23.

Seuntjens, T., van de Ven, N., Zeelenberg, M. and van der Schors, A. 2016, 'Greed and Adolescent Financial Behavior’, Journal of Economic Psychology, vol. 57, pp. 1-12.

Shim, S., Xiao, J., Barber, B. and Lyons, A. 2009, 'Pathways to Life Success: A Conceptual Model of Financial Well-Being for Young Adults', Journal of Applied Developmental Psychology, vol. 30, pp. 708-23.

Sorgente, A. and Lanz, M. 2017, ‘Emerging Adults’ Financial Well-Being: A Scoping Review’, Adolescent Research Review, vol. 2, pp. 255-92.

Summerfield, M., Bevitt, A., Fok, K., Hahn, M., La, N., Macalalad, N., O’Shea, M., Watson, N., Wilkins, R. and Wooden, M. 2019, HILDA User Manual Release 17, Melbourne Institute of Applied Economic and Social Research, Melbourne.

Sutter, M., Zoller, C. and Glätzle-Rützler, D. 2018, 'Economic Behavior of Children and Adolescents-A First Survey of Experimental Economics Results’, IZA Discussion Paper no. 11947, IZA, Bonn.

Van den Bree, M., Shelton, K., Bonner, A., Moss, S., Thomas, H. and Taylor, P. 2009, 'A Longitudinal Population-based Study of Factors in Adolescence Predicting Homelessness in Young Adulthood', Journal of Adolescent Health, vol. 45, pp. 571-78.

Wood, D., Griffiths, K., and Emslie, O. 2019, Generation Gap: Ensuring a fair go for younger Australians. Grattan Institute, Melbourne.

This article is protected by copyright. All rights reserved. 


\section{University Library}

\section{- M M I N E R VA A gateway to Melbourne's research publications}

Minerva Access is the Institutional Repository of The University of Melbourne

Author/s:

de New, J;Ribar, D;Ryan, C;Wong, C

Title:

Financial Outcomes in Adolescence and Early Adulthood in Australian Longitudinal Data

Date:

2020-03-01

Citation:

de New, J., Ribar, D., Ryan, C. \& Wong, C. (2020). Financial Outcomes in Adolescence and Early Adulthood in Australian Longitudinal Data. The Australian Economic Review, 53 (1), pp.126-138. https://doi.org/10.1111/1467-8462.12361.

Persistent Link:

http://hdl.handle.net/11343/276847 